\title{
A Modified Method for the Turbidimetric Assay of Nisin
}

\author{
Simone Hickmann Flôres ${ }^{1 *}$, Ana Luíza de Mattos Braga ${ }^{2}$ and Ranulfo Monte Alegre ${ }^{3}$ \\ ${ }^{1}$ Faculdade de Engenharia de Alimentos; DCA;ICTA; UFRGS; Avenida Bento Gonçalves, 9500, Agronomia; \\ 91501-970; siflores@bol.com.br; Porto Alegre - RS - Brazil. ${ }^{2,3}$ Faculdade de Engenharia de Alimentos; \\ DEA;UNICAMP; C. P. 6121; 13083-970; ranulfo@fea.unicamp.br; Campinas - SP - Brazil
}

\begin{abstract}
Nisin is an antibacterial peptide produced by Lactococcus lactis subsp. lactis that shows a broad spectrum of inhibitory activity against gram-positive microorganism including bacterial spores. Methods for nisin activity estimation in solution is redefined. In this work a new turbidimetric assay method has been described making possible to assay nisin satisfactorily in total incubation period of approximately six hours.
\end{abstract}

Key words: lantibiotic, nisin, Lactococcus lactis, turbidimetric assay

\section{INTRODUCTION}

Nisin is a bacteriocin of the lantibiotic type produced by certain strains of Lactococcus lactis subsp. lactis. It is composed of 34 amino acids and has molecular weight of 3354, which displays a bactericidal mode of activity (Hurst, 1981). The biosynthesis of nisin occurs in two steps: a precursor peptide (prenisin) is synthesised ribosomally followed by post-translational enzymatic modifications converting the inactive precursor into a mature bioactive peptide. These modifications include dehydration of specific amino acids serine and threonine residues, with subsequent addition of neighbouring cysteine sulphur to the double bounds of the didehydroamine acids resulting in the formation of thioether bridges (De Vuyst, 1995).

Nisin was first introduced as a food preservative in the U.K. approximately 30 years ago. Its use was first established as preservative in processed cheese products and since then numerous other applications in food and beverages have been identified. It is currently recognised as a safe food preservative in approximately 50 countries. Nowadays, production of highly purified nisin preparations and enhancement by chelators has led to interest in the use of nisin for human ulcer therapy and mastitis control in the cattle (Delves Broughton et al., 1996).

In this work a new turbidimetric assay method has been described being possible to assay nisin satisfactorily in total incubation period of approximately six hours.

\section{MATERIAL AND METHODS}

Nisin (2.5\%) was obtained from Sigma and stored at $4^{\circ} \mathrm{C}$. Lactococcus lactis subsp. cremoris was used as test microorganism. The test microorganism was cultured in Erlenmeyers flasks with $300 \mathrm{ml}$ of medium with the following composition $(\% \mathrm{w} / \mathrm{v})$ : meat extract, 1 ; yeast extract, 1; tryptone, 1; glucose, $1 ; \mathrm{NaCl}, 0.5 ; \mathrm{Na}_{2} \mathrm{HPO}_{4}$, $0.2 ; \mathrm{pH} 7.0$. After fermentation the medium was

\footnotetext{
* Author for correspondence
} 
distributed in deep tubes containing glycerol $(5 \mathrm{ml}$ of cultured medium and $5 \mathrm{ml}$ of glycerol) and stored frozen. The tubes were used as inocolum for subsequent assays.

To obtain growth curve of test microorganism, the samples were collected at each hour and their O.D. were measured spectrophotometrically at $600 \mathrm{~nm}$. Since the growth of the test microorganism reached the stationary phase in six hours of incubation, it was defined as the incubation time to draw the standard curve of nisin as well as to determine nisin concentration in other solutions.

Nisin standard: $0.05 \mathrm{~g}$ of nisin $(2.5 \%)$ was dissolved in $50 \mathrm{ml} 0.01 \mathrm{~N} \mathrm{HCl}$ and further dilutions were made in order to obtain a standard concentration in the range of 0.2 to $1.0 \mu \mathrm{g} / \mathrm{ml}$.

Bioassay of nisin: One tube of the test microorganism pre-cultured was diluted with 300 $\mathrm{ml}$ of free basic medium with the following composition $(\mathrm{w} / \mathrm{v})$ : sucrose 10 , peptone 10 , yeast extract 10, $\mathrm{KH}_{2} \mathrm{PO}_{4} 10, \mathrm{NaCl} 2$ and $\mathrm{Mg}_{2} \mathrm{SO}_{4} \cdot{ }_{7} \mathrm{H}_{2} \mathrm{O}$ 0.4 . Five $\mathrm{ml}$ of this culture was distributed in deep tubes containing $5 \mathrm{ml}$ of this same basic free medium plus $1 \mathrm{ml}$ of nisin solution containing different concentrations. In the control tube the nisin solution was replaced by $1 \mathrm{ml}$ of medium. All tubes were incubated at $37^{\circ} \mathrm{C}$ without shaking for six hour and their O.D. were measured at 600 $\mathrm{nm}$. The growth was stopped by injecting into each tube $1 \mathrm{ml}$ of $0.004 \%$ of thiomersalate solution. A series of standards were set-up in triplicate for each assay.

\section{RESULTS AND DISCUSSION}

Figure 1 shows the best polynomial line drawn with its respective equation. It was observed that 1 x $10^{-7} \mathrm{~g} / \mathrm{ml}$ nisin concentration caused complete inhibition of the Lactococcus lactis subsp. cremoris. In the control tube, the nisin solution must be replaced by the same medium without nisin.

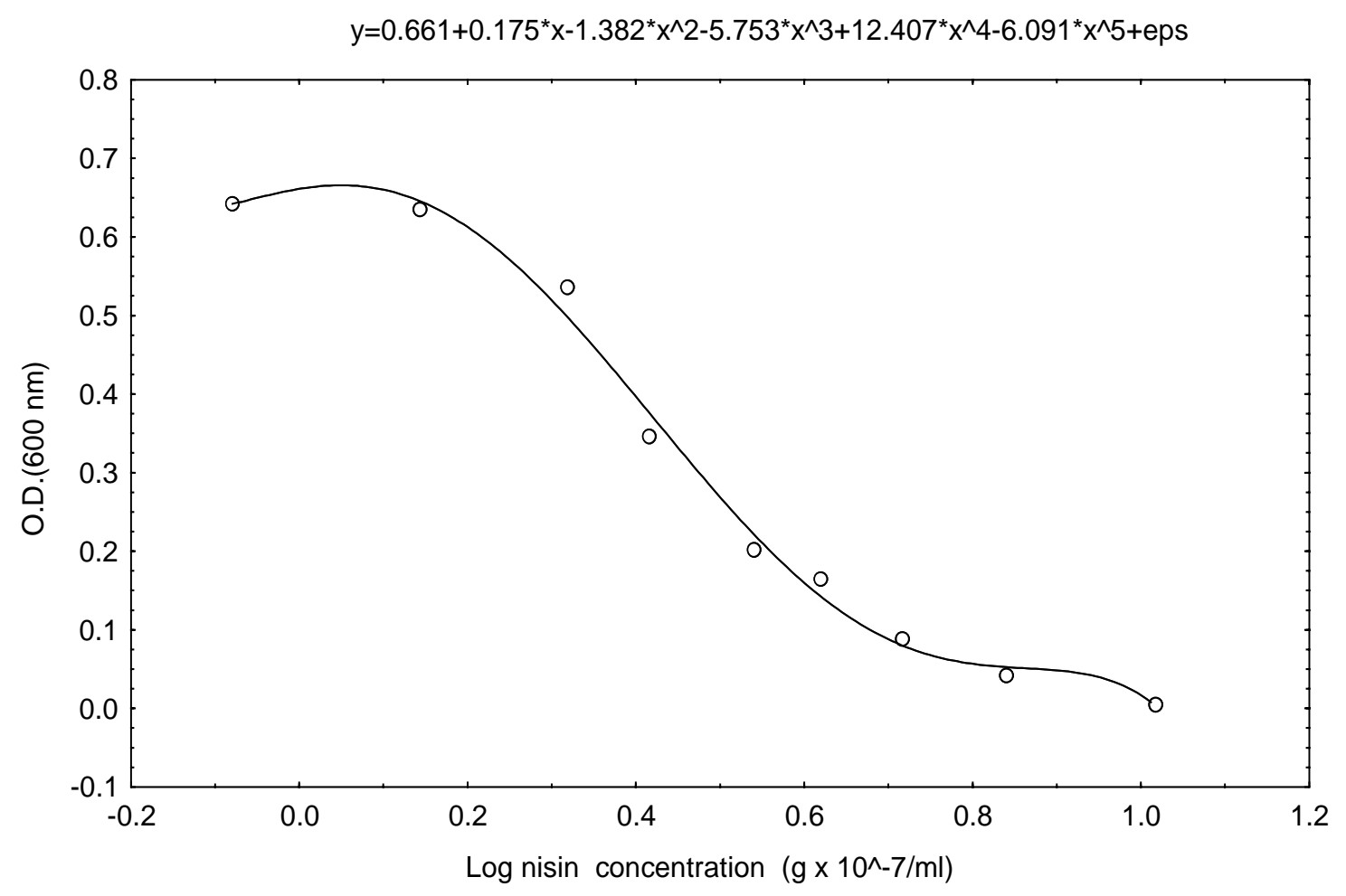

Figure 1 - Standard curve Nisin 
By the assay, it was possible to obtain different samples of cultures containing nisin. This method follow the Hurst (1966) method and was modified because Lactococcus lactis subsp cremoris showed a different behavior when compared with Streptococcus cremoris (1 P5) used by Hurst. Thus, it was necessary to obtain a particular curve and also to adapt this method as a faster and more precise method. Hurt (1966) obtained a similar growth response of nisin standard curve. This modified method showed to be faster and more precise for nisin activity determination than others methods, like the plate diffusion assays described by Tramer and Fowler (1964). The major limitation of plate diffusion assays is that nisin diffusion agar media is proportional to the concentration of nisin only over a limited linear range and nisin levels should be restricted to this range if accurate assessment is to be achieved. Beyond this range, the zone diameters cannot be accurately related directly to the concentration of nisin. Chandrapati and O'Sullivan (1998) developed a modified rapid plate assay procedure that allowed quantifiable measurement of nisin production by Lactococcus lactis growing directly on agar media. Using this direct plate assay, several nutritional parameters were assessed for their influence on nisin production by Lactococcus lactis ATCC 11454 growing on standard M17 based media over 3 and $6 \mathrm{~h}$ incubation periods. But the total time of assay is between 15 and $18 \mathrm{~h}$ because the indicator organism (M. luteus) was incubated for 10-12 hours.

Falahee et al. (1990) developed an enzyme-linked immunosorbent assay (ELISA) for nisin using polyclonal antiserum but this method has a limit of detection of $1.9 \times 10^{-2} \mathrm{IU} / \mathrm{mL}$. Hurst (1966) used overnight cultures of the test organism Streptococcus lactis (1P5), diluted with fresh medium and incubated at $30^{\circ} \mathrm{C}$ for 1 hour. This step was repeated 2-3 times to get a vigorously growing culture; when a $1 / 10$ dilution of such culture had an extinction value of 0.1 at $600 \mathrm{~nm}$. This latter culture was used to inoculate $(1 \%, \mathrm{v} / \mathrm{v})$ one litre of the same medium which was incubated for 1 hour at $30^{\circ} \mathrm{C}$. Then further dilutions were made as quickly as possible and the tubes were incubated for 3 hours.

With our modified method, it was also possible to eliminate some steps of the Hurst method as successive dilutions and incubations of test microorganism and to obtain similar results in only 6 hours.

\section{RESUMO}

Nisina é um peptídeo antibacteriano produzido por Lactococcus lactis subsp lactis que apresenta um grande espectro antimicrobiano para microrganismos gram-positivos incluindo esporos bacterianos. Alguns métodos para deteminação da atividade de nisina foram definidos. Neste trabalho foi proposto uma modificação no método para determinação de nisina no qual obteve-se resultados satisfatórios em aproximadamente 6 horas.

\section{ACKNOWLEDGEMENT}

This work was supported by Fundação de Apoio a Pesquisa do Estado de São Paulo.

\section{REFERENCES}

Berridge, N. J. and Barret, J. (1952), A Rapid method for the turbidimetric assay of antibiotics. Journal of General Microbiology, 6, 14-20.

Chandrapati, S and O' Sullivan, D. J. (1998), Procedure for quantifiable assessment of nutritional aprameters influencing Nisin production by Lactococcus lactis subsp lactis. Journal of Biotechnology, 63, 229-233.

Delves-Broughton, J.; Blackburn, P.; Evans S. R. J. and Hugenholtz, J. (1996), Applications of the bacteriocin, nisin. Antonie van Leeuwenhoek, 69, 193-202.

De Vuyst, L. (1995), Nutritional factors affecting nisina production by Lactococcus lactis subsp. Lactis. Applied Bacteriology, 78, 28-33.

Falahee, M. B.; Adams, M.R., Dale, J.W. and Morris, B. A (1990), Na Enzyme immunoassay for nisin. International Journal of Food Science and Technology, 25, 590-595.

Hurst, A. (1966), Biosynthesis of the antibiotic Nisin Whole Streptococcus lactis Organism. Journal of General Microbiology, 44, 209-220.

Hurst, A. (1981), Nisin. Advances in Applied Microbiology, 27, 85-123.

Tramer, J. and Fowler, G. G. (1964), Estimation of Nisin in Foods. Journal Science Food Agriculture, 15, 522-528. 